\title{
Thesis Guides
}

Theses in Canada: A Guide to.Sources of Information about Theses Completed or in Preparation / Thèses au Canada: Guide sur les sources documentaires relatives aux thèses complétées ou en cours de rédaction. Compiled by / Compilé par Susan (Jaques) Bruchet and / et Gwynneth Evans. Ottawa: National Library of Canada / Bibliothèque nationale du Canada, I978. 25 p., paper, free. Supply and Services Canada Cat. No. SN-87/1978. ISBN 0-662OI620-3

Canada: A Dissertation Bibliography. Ann Arbor, Mich.; London, Eng.: University Microfilms International, 1975. I6 p., paper, free.

The past twenty years have witnessed a spectacular growth in the numbers of students completing advanced degrees in Canada's graduate schools. Co-incidentally a lively interest in matters Canadian has prevailed in academic institutions outside this country. An important but often ignored and undervalued product of these intellectual endeavours is the graduate thesis which, from the bibliographer's perspective, is usually a veritable treasure trove. The relative obscurity of the thesis is easily explained. Few copies are printed in the original form. The thesis rarely is published commercially in its entirety, its author opting rather for papers in professional journals and monographs with limited printings. And secondly, knowledge of the titles and the availability of theses is poorly expressed both inside and beyond the academic pale. The two items reviewed here should alleviate somewhat the present unnecessary obscurity of the intellectual endeavours of so many earnest minds.

Canadian theses are listed in the national bibliography, Canadiana, and in other National Library of Canada publications providing bibliographic control and access to Canadian thesis literature (e.g. Canadian Theses / Thèses canadiennes and Canadian Theses on Microfiche: Catalogue). The National Library also sells theses to the public on microfilm and microfiche at $\$ 15.00$ and $\$ 5.00$ respectively for each thesis. These arrangements notwithstanding, there continue to be many requests for lists of Canadian theses by subject. Theses in Canada / Thèses au Canada is a response by two staff members of the National Library to these requests. The information is presented under three headings: General Bibliographies, Theses Lists by University, and Specialized Bibliographies. The volume contains information on sources, monographic and serial, which record the theses written in partial fulfilment of the requirements for a graduate degree from Canadian universities. Omitted, however, are theses written by Canadians in universities abroad or theses on Canadian topics written in foreign universities by Canadians and others. The compilers identify the latter as being recorded in publications such as Michael M. Reynolds' Guide to Theses and Dissertations: An International Annotated Bibliography of Bibliographies (Detroit, Mich.: Gale Research, I975).

The omissions identified by Bruchet and Evans are rectified, to a degree, by the appearance of Canada: A Dissertation Bibliography. Though it is an information and sales catalogue rather than a formal publication, this listing of more than $\mathrm{I}, 000$ doctoral titles relevant to Canada and Canadiana signifies the importance attached to dissertations with a Canadian orientation by University Microfilms International 
(UMI). The catalogue is 'a representative listing of Dissertations accepted by North American Universities and available as full text reproductions' from UMI. (Interestingly most of the theses listed were completed at schools in the United States.) Each dissertation cited appeared in abstract form in Dissertation Abstracts International (DMI) and is listed here alphabetically by author within subject area. Each entry also includes full title, degree earned, school name, date of degree, number of text pages, citation to DMI (volume, issue, page number), and the order number for purchasing the full-text reproduction. Prices effective March I5, I978 for dissertation and master thesis copies are: microform ( $35 \mathrm{~mm}$ and microfiche) us $\$ 8.25$ (academic) us $\$$ II .oo (other); xerographic us $\$ 16.50$ (academic), us $\$ 22.00$ (other).

Many readers will be familiar with UMI's Comprehensive Dissertation Index (CDI) which, according to its compilers, contains bibliographic information 'on almost every doctoral dissertation accepted in North America since I86r'. Computer searches (Datrix II) of the CDI database using keywords or on-line search services and full text reproduction are some of the normal components of the thesis information retrieval system.

The volume compiled by Bruchet and Evans is recommended to all with an interest in the availability of Canadian theses. And Canada: A Dissertation Bibliography should be specifically cited when requesting an information package from UMI.

ROBERT C. SCACE

(Dr. Scace, a geographer with Reid, Crowther $\Theta$ Partners Limited, Consulting Engineers and Planners, Calgary, Alberta, has prepared a number of bibliographies on the national parks of Western Canada.)

\section{And another impression of Theses in Canada:}

With the publication of Theses in Canada, another item is added to the growing list of bibliographies of bibliography. This particular work has been prepared in response to a demand for such a source and is first and foremost a professional tool. The citations, which contain sufficient information to identify uniquely each source, refer either to separately-published monographs, listing theses exclusively or amongst other items, or to serial publications which include bibliographies containing varying numbers of theses. Most of these lists of theses have been compiled and published within the last five to ten years, so they should be readily available.

Items in Theses in Canada are grouped into three categories: General Bibliographies, Theses Lists by University, and Specialized Bibliographies. There is no compiler or publisher index. Access is provided by a table of contents at the front of the work. The third category, Specialized Bibliographies, is subdivided into 17 subject categories. However, while the English subjects are arranged alphabetically on the left of the contents page, the French subjects in the right-hand column are not so arranged, being provided solely as a translation. While scanning the short list is not time-consuming, an alphabetically-arranged French table of contents would provide equal access for Francophone users.

The general bibliographies are evenly divided between works with a Canadian or a non-Canadian imprint. The list of theses arranged by university is a useful feature. All are Canadian institutions, but only nine are mentioned - perhaps theses lists from the 
others have not been compiled. In the listing of specialized bibliographies, the percentage of Canadian-produced titles is high, but of those lists published elsewhere, the information given about their Canadian content varies considerably. One or two entries include the statement 'some Canadian theses' or 'a few Canadian theses' - this feature should be expanded in future editions. Otherwise, the user can only find out how useful a source will be by picking it up and going through it. The section under Area Studies on the USSR illustrates the problem.

A couple of inconsistencies in the form of corporate names were noticed, mainly because they appeared on the same page. 'University Laval' is used next to 'Université Laval' on page three, while there is use of both the 'Canadian Education ...' and '... Educational Association' on page twelve. Only one duplicate entry was found, and this was for an item having a dual subject focus (pages 4 and 5 , Dobson).

In conclusion, Theses in Canada is a useful start on the provision of access to Canadian theses. An indication of the frequency of revisions planned would be useful, and it is hoped that the more general lists published outside Canada will be replaced with Canadian sources, as and when they appear.

DEBORAH C. SAWYER

(Ms. Sawyer is Editor and Managing Editor of the Canadian Education Index and of the Directory of Education Studies in Canada, Toronto). 